Eur J Clin Chem Clin Biochem

1995; 33:737-742

(c) 1995 Walter de Gruyter \& Co.

Berlin · New York

\title{
Automated Fluorimetric Assay Procedure for Glucohydrolases Using a Routine Centrifugal Analyser Assay of Enzymes of Lysosomal Origin in Plasma, $\mathrm{II}^{1}$ )
}

By Giancarlo Goi ${ }^{1}$, Emma Guagnellini ${ }^{2}$, Chiara Bairati ${ }^{1}$, Marco Besozzi ${ }^{3}$, Adriana Lombardo ${ }^{1}$, Donatella Bollini ${ }^{1}$, Augusto Lovagnini ${ }^{4}$ and Guido Tettamanti ${ }^{1}$

1 Department of Medical Chemistry and Biochemistry, The Medical School, University of Milan, Milan, Italy

2 Laboratory of Clinical Chemistry, S. Paolo Hospital, Milan, Italy

${ }^{3}$ Laboratory of Clinical Chemistry, Legnano Hospital, Legnano (Milan), Italy

4 Laboratory of Clinical Chemistry and Microbiology, Bassini Hospital, Cinisello Balsamo (Milan), Italy

(Received February 28/June 23, 1995)

Summary: The manual fluorimetric procedure, considered as a reference method for the determination of $\mathrm{N}$-acetyl$\beta$ - $D$-glucosaminidase, $\beta$ - $D$-glucuronidase and $\beta$ - $D$-galactosidase in human plasma, was automated as a routine method, using the IL Monarch centrifugal analyser. Using a liquid standard with a known enzyme content, the automated assay correlated fairly well with the reference manual method ( $\mathrm{r}$ values very close to 1 ). Its analytical imprecision was much lower than that of the manual method. The automated assay of $N$-acetyl- $\beta$ - $D$-glucosaminidase, $\beta-D$-glucuronidase and $\beta-D$-galactosidase gave coefficients of variation of 5.7-6.9, 3.6-5.0 and 3.8-4.2\%, respectively, detection limits of 4,2 and $1 \mathrm{mU} / 1$ plasma respectively, and linear responses of up to $73,8.4$ and 0.9 $\mathrm{U} / \mathrm{l}$ of plasma respectively. Furthermore, the method required only small volumes of undiluted plasma $(4-10 \mu \mathrm{l})$. This method appears to be reliable, sensitive, simple enough for routine analyses and as cost effective as the most common routine serum enzyme assays.

\section{Introduction}

There is evidence that the determination, in body fluids, of enzymes of lysosomal origin has potential value in the diagnosis of a number of diseases $(1-7)$. For instance, the plasma levels of lysosomal enzymes have been shown to correlate with the metabolic control of diabetes $(8-12)$, and with the functional conditions of kidney and liver $(13-14)$, the latter organ being implicated in the clearance of the same enzymes (15). Interestingly, the plasma determination of some lysosomal enzymes has been suggested for monitoring the functional recovery of the liver after transplantation (16).

A realistic assessment of the diagnostic potential of lysosomal enzymes requires the availability of simple, re-

\footnotetext{
1) Part I 1.c. (19)
}

liable, low cost assay procedures, suitable for routine analyses. At present, sensitive optimized and reproducible fluorimetric methods are available for the determination of lysosomal enzymes in plasma (17), including the isozymes of $\mathrm{N}$-acetyl- $\beta$ - $D$-glucosaminidase (18). Also, stable reference materials can be prepared for instrument calibration and for running of intra- and interlaboratory quality control programmes (19). The only obstacle to the routine application of these methods is the fact that they are manual.

On these premises and considering the wide availability in clinical laboratories of the IL Monarch centrifugal analyser equipped with a fluorimetric detector, we decided to adapt the manual fluorimetric procedure for lysosomal enzyme assays to this automated instrument, using the reference calibration material prepared in our 
Tab. 1 Operational conditions for the automated assay of three enzymes of lysosomal origin using the IL Monarch

\begin{tabular}{|c|c|c|c|c|}
\hline & $\begin{array}{l}\mathrm{N} \text {-Acetyl- } \beta \text { - } D \text {-glucos- } \\
\text { aminidase }\end{array}$ & $\beta$ - $D$-Glucuronidase & & $\beta$ - $D$-Galactosidase \\
\hline Response algorithm & Final Point & Final Point & & Final Point \\
\hline Results algorithm & linear & linear & $\cdot 1$ & linear \\
\hline Loading type & \multicolumn{4}{|c|}{ Load-(crit) incubate-reload-analyse (for all enzymes) } \\
\hline Reagent blank & On & On & & On \\
\hline Sample volume, $\mu \mathrm{l}$ & 4 & 7 & & 10 \\
\hline Sample diluent, $\mu \mathrm{l}$ & 0 & 0 & & 0 \\
\hline 2nd reagent, $\mu \mathrm{l}$ (buffer-substrate sol.) & 55 & 55 & & 55 \\
\hline - buffer (mmol/n)* & 54 & 57 & & 59 \\
\hline$-\mathrm{pH}$ & 4.2 & 3.6 & & 3.3 \\
\hline - substrate $(\mathrm{mmol} / \mathrm{l})$ & 6.5 & 4.6 & & 2.4 \\
\hline 3rd -4 th reagent, $\mu \mathrm{l}$ (glycine solution) & $135-40$ & $135-40$ & & $135-40$ \\
\hline & \multicolumn{4}{|c|}{$0.2 \mathrm{~mol} / \mathrm{l}$ glycine- $\mathrm{NaOH}, 0.125 \mathrm{~mol} / \mathrm{/} \mathrm{NaCl}, \mathrm{pH} 10.75$ (for all enzymes) } \\
\hline Temperature, ${ }^{\circ} \mathrm{C}$ & 37 & 37 & & 37 \\
\hline Incubation time, $\min$ & 5 & 5 & & 10 \\
\hline Delay time, $s$ & 20 & 20 & & 20 \\
\hline Interval time, $s$ & 10 & 10 & & 10 \\
\hline Filter 1 and $2, \mathrm{~nm}$ & 450 & 450 & & 450 \\
\hline Monochromator 1 and 2, nm & 365 & 365 & & 365 \\
\hline
\end{tabular}

* citric acid-sodium citrate for $N$-acetyl- $\beta$ - $D$-glucosaminidase and acetic acid-sodium acetate for $\beta$ - $D$-glucuronidase and $\beta$ - $D$-galactosidase

laboratory (19). The three enzymes ${ }^{2}$ ) of lysosomal origin with the highest diagnostic potential, $\mathrm{N}$-acetyl- $\beta-D$-glucosaminidase, $\beta$ - $D$-glucuronidase and $\beta$ - $D$-galactosidase, were determined in human plasma. The results showed that all three enzymes can be routinely determined on the IL Monarch centrifugal analyser, simply and reliably, and at relatively low cost.

\section{Materials and Methods}

\section{Chemicals and other products}

Commercial chemicals were of the highest purity available. The water routinely used was freshly redistilled in a glass apparatus. 4Methylumbelliferone, purchased from Fluka $\mathrm{GmbH}$ (Buchs, Switzerland), was recrystallized three times from ethanol; 4-methylumbelliferyl-glycosides, used as substrates for the individual glycohydrolases, were purchased from Melford (Suffolk, England); ethylene glycol, haemoglobin and bilirubin from Sigma Chem. Co (St. Louis, Mo, USA); intralipid from Cutter Labs. Inc. (Berkeley, CA 94710).

\section{Blood sampling and preparation of plasma specimens}

Plasma was prepared from blood treated with sodium citrate (final concentration: $11 \mathrm{mmol} / \mathrm{l}$ ), which is known not to affect lysosomal enzyme activities (17). Ethylene glycol was added (300 g/l) to the

\section{2) Enzymes:}

$N$-acetyl- $\beta-D$-glucosaminidase:

$\mathrm{N}$-acetyl- $\beta$ - $D$-glucosaminide $\mathrm{N}$-acetylglucosaminohydrolase, EC 3.2.1.30

$\beta$ - $D$-galactosidase:

$\beta$-D-galactoside galactohydrolase EC 3.2.1.23

$\beta$ - $D$-glucuronidase:

$\beta$ - $D$-glucuronoside glucuronosohydrolase EC 3.2.1.31 plasma samples immediately after collection (19). The samples were then stored at $-20^{\circ} \mathrm{C}$ until assayed.

Blood was withdrawn from two groups of individuals. The first group provided plasma to be used for studying the analytical characteristics of the method (total imprecision, sensitivity) and for evaluating possible interferences. These individuals, who were informed of the puropse of the investigation, were healthy adults, both males and females, aged 25-55 years, mostly volunteer blood donors. Some of them were women in the final trimester of pregnancy. In all cases blood was withdrawn immediately before the control laboratory analyses, and the common blood analytes were found to be within normal ranges. Care was taken to check the absence of antibodies indicative of particular infectious diseases, like AIDS and hepatitis, in all the specimens collected. The plasma specimens were divided into three pools:

pool A, carrying high lysosomal enzyme activities, obtained by pooling plasma from the pregnant women, who are known to have elevated plasma levels of these enzymes (20);

pool B, carrying medium levels of lysosomal enzyme activities, obtained by pooling plasma from normal individuals;

pool C, carrying low levels of lysosomal enzyme activities, obtained by dilution $1+1$ pool B with a sample of the same pool B in which lysosomal enzymes had been inactivated by heating at $56^{\circ} \mathrm{C}$ for 5 hours (O pool) (19).

Owing to the extremely low, if any, enzyme activities in the " $O$ pool", the same pool was also utilized to study the sensitivity of the method.

A different plasma pool containing intermediate activity was prepared for use as a "standard" for the automated instrument. The enzyme levels of this standard were established by the manual method.

The second group of individuals provided the plasma specimens used to compare the routine automated method with the manual method. This group comprised 60 randomly chosen individuals who entered the Laboratory of Clinical Ghemistry and Microbiology of the Bassini Hospital for scheduled haemato-chemical tests. 


\section{Linearity of the automated method}

To assess the linearity of the automated method, we studied saples made from various proportions of serum pools with extreme levels of lysosomal enzyme activities. The expected (theoretical) values were calculated from the corresponding values of the original pools. Each determination was performed in triplicate.

\section{Imprecision of the automated method}

The analytical imprecision of the automated method was studied using plasma pools A, B and C. Two replicate analyses were performed for each enzyme in twenty different analytical series, covering a period of three months, according to the model of Krouwer (21) and NCCLS recommendations (22).

Fluorimetric assay of lysosomal enzymes on the "IL Monarch" centrifugal analyser

The following enzymes of lysosomal origin were assayed fluorimetrically: $N$-acetyl- $\beta-D$-glucosaminidase, $\beta$ - $D$-glucuronidase, $\beta$ $D$-galactosidase, using the corresponding 4-methylumbelliferyl glycosides as substrates. The manual assay procedure for these enzymes, provisionally adopted as the reference method, was as described (17).
The automated procedure was developed by adapting the assay conditions of the manual method to the random access centrifugal analyser IL Monarch (Instrumentation Laboratory, Lexington, MA, USA). For fluorimetric analysis this instrument uses disposable reaction rotors made of UV-transmitting plastic material. The basic operating conditions were those suggested by the manufacturer. The plasma specimens were thawed immediately before use, brought to room temperature and employed as such without dilution. The nature, $\mathrm{pH}$ and concentration of the buffer, substrate molarity and the time of incubation at $37^{\circ} \mathrm{C}$ were chosen to give the optimal values for each enzyme activity, and they were found to be the same as those already established for the manual method (17). Details of the conditions used to measure lysosomal enzyme activities on the IL Monarch centrifugal analyser are given in table 1. Regular incubation mixtures containing physiological saline in place of plasma were used as controls (blanks).

All enzyme activities were expressed as units $(U, \mu$ moles hydrolysed substrate, $\min ^{-1}$ ) per litre.

Interference in the determination of plasma lysosomal enzymes by the routine automated method

For this purpose the plasma was added with increasing amounts of haemolysate (prepared from human erythrocytes), lipids (as Intralipid) and bilirubin, following the indication of Glick et al. (23). The
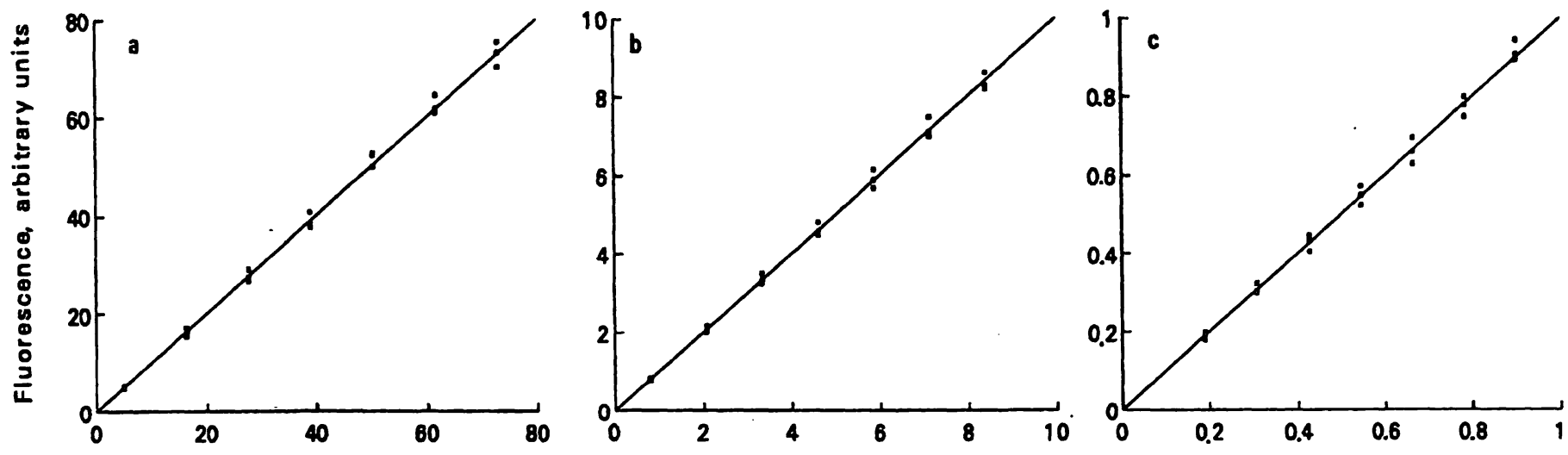

Catalytic concentration (expected values) [U/I]

Fig. 1 Linearity of the automated method for the determination of $N$-acetyl- $\beta$ - $D$-glucosaminidase (a), $\beta$ - $D$-glucuronidase (b) and $\beta$ - $D$-galactosidase (c) in human plasma. For details see the experimental section.

Tab. 2 Estimation of the imprecision of the automated method for the assay of lysosomal enzymes in plasma.

\begin{tabular}{|c|c|c|c|c|c|c|}
\hline \multirow[t]{3}{*}{ Enzyme } & \multirow{3}{*}{$\begin{array}{l}\text { Plasma } \\
\text { pool }\end{array}$} & \multicolumn{4}{|c|}{ Automated method } & \multirow{3}{*}{$\begin{array}{l}\text { Manual method } \\
\text { Coefficient of } \\
\text { variation (\%) } \\
\text { Total }\end{array}$} \\
\hline & & \multirow{2}{*}{$\begin{array}{l}\text { Enzyme activity } \\
(\mathrm{mU} / \mathrm{l}) \\
\text { Mean }\end{array}$} & \multicolumn{3}{|c|}{ Coefficient of variation (\%) } & \\
\hline & & & Within-run & Day to day & Total & \\
\hline $\mathrm{N}$-Acetyl- $\beta-D-$ glucosaminidase & $\begin{array}{l}\text { A } \\
\text { B } \\
\text { C }\end{array}$ & $\begin{array}{r}42100 \\
28000 \\
8200\end{array}$ & $\begin{array}{l}3.9 \\
3.7 \\
3.6\end{array}$ & $\begin{array}{l}4.2 \\
4.7 \\
5.9\end{array}$ & $\begin{array}{l}5.7 \\
5.9 \\
6.9\end{array}$ & $\begin{array}{l}5.2 \\
5.5 \\
9.5\end{array}$ \\
\hline$\beta$ - $D$-Glucuronidase & $\begin{array}{l}\text { A } \\
\text { B } \\
\text { C }\end{array}$ & $\begin{array}{l}4700 \\
2400 \\
1100\end{array}$ & $\begin{array}{l}3.2 \\
3.0 \\
4.5\end{array}$ & $\begin{array}{l}0.5 \\
2.0 \\
2.2\end{array}$ & $\begin{array}{l}3.6 \\
4.1 \\
5.0\end{array}$ & $\begin{array}{r}4.2 \\
4.4 \\
11.9\end{array}$ \\
\hline$\beta-D$-Galactosidase & $\begin{array}{l}\text { A } \\
\text { B } \\
\text { C }\end{array}$ & $\begin{array}{l}700 \\
300 \\
140\end{array}$ & $\begin{array}{l}3.5 \\
3.5 \\
3.6\end{array}$ & $\begin{array}{l}0.2 \\
1.1 \\
1.2\end{array}$ & $\begin{array}{l}3.8 \\
4.1 \\
4.2\end{array}$ & $\begin{array}{r}9.3 \\
14.7 \\
17.5\end{array}$ \\
\hline
\end{tabular}


haemoglobin content in haemolysate was quantified by measuring the cyanomethaemoglobin derivative (24).

\section{Statistical analysis}

Parametric techniques of analysis were employed. Regression analysis and correlation coefficients were calculated following the Snedecor \& Cochran indications (25) for linearity study and with the standard model of Derming (26) for comparison of methods study. The estimation of total imprecision by analysis of variance was performed following the model of Krouwer (21), and NCCLS recommendations (22).

\section{Results}

Application of the manual method to a routine centrifugal autoanalyser, namely the IL Monarch, presented no particular difficulties, provided the manufacturer's instructions were rigorously followed. The only discrepant finding was the instrument's response to the liberated fluorophore, 4-methylumbelliferone, which was about three-fold lower with the autoanalyser than with the spectrofluorimeter employed in the manual method. This difference, which remained unchanged after careful calibration of the autoanalyser with 4-methylumbelliferone solutions of known concentration, was found to be related to the plastic cuvettes used in the centrifugal analyser. However, when the stable liquid material was used as an analytical internal standard (see later), the method sensitivity remained practically unaffected.

The detection limits, calculated as the minimal enzyme activity detectable above the mean plus three standard deviations measured daily for 15 days in triplicate, were $4.0,2.0,1.0 \mathrm{mU} / 1$ for $\mathrm{N}$-acetyl- $\beta-D$-glucosaminidase, $\beta$ $D$-glucuronidase and $\beta$ - $D$-galactosidase, respectively.

As shown in figure 1 , linearity was assured within a relatively wide range of enzyme concentrations (up to $73,8.4$ and $0.9 \mathrm{U} / 1$ of plasma for $\mathrm{N}$-acetyl- $\beta$ - $D$-glucosaminidase, $\beta$ - $D$-glucuronidase and $\beta$ - $D$-galactosidase, respectively). The correlation coefficients were very high $(r=0.999)$ for all enzymes and no significant differences in the internal consistency of the linear regression were detectable.

With the plasma pools of low, medium and high enzyme levels, the automated method showed low and acceptable coefficients of variation: from 5.7 to 6.9 for $\mathrm{N}$-acetyl- $\beta$ - $D$-glucosaminidase, from 3.6 to 5.0 for $\beta$ - $D$-glucuronidase and from 3.8 to 4.2 for $\beta-D$-galactosidase, the lower values applying to the plasma pool with the highest enzyme activity (tab. 2). Moreover, and as expected, the degree of imprecision decreased with increasing the enzyme concentration in the sample. It is noteworthy that the degree of imprecision was much lower with the automated method than with the manual one (19).
The data in figure 2 on the effects of potential interferents show that haemoglobin did not interfere in the determination of these lysosomal enzymes, bilirubin exhibited a very modest $(-8 \%)$ inhibition effect on the enzyme determination, while lipids (as intralipid) caused an increase of $\beta-D$-galactosidase $(40 \%$ at $10 \mathrm{~g} / \mathrm{l})$, without affecting the determination of the other enzymes.

As shown in figure 3 the correlation between the automated and the manual method, for plasma from 60 individuals, was good for all the considered enzymes. The response of the automated method appeared to be markedly lower than that of the manual one, especially for $\beta$ $D$-galactosidase, and the $r$ values, although good, were further from unity for $\mathrm{N}$-acetyl- $\beta-D$-glucosaminidase and $\beta-D$-glucuronidase. However, the use of the stable liquid material as analytical standard material made the results of the automated method practically identical to those of the manual one for all enzymes, and increased
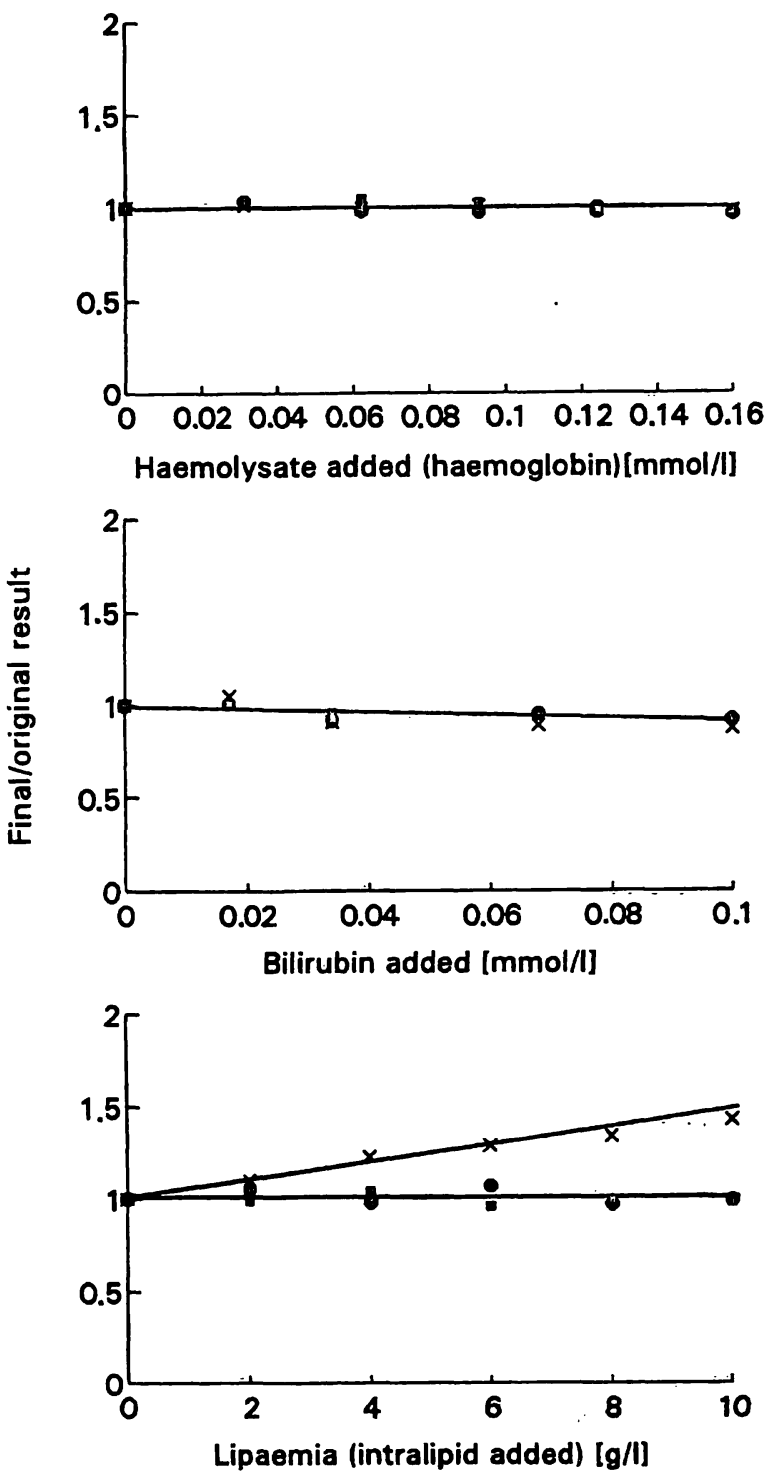

Fig. 2 . Interference by haemoglobin, bilirubin and intralipid in the determination of plasma $N$-acetyl $-\beta-D$-glucosaminidase $\varphi, \beta$ $D$-glucuronidase $\square$ and $\beta$ - $D$-galactosidase $x$ by the automated procedure. 

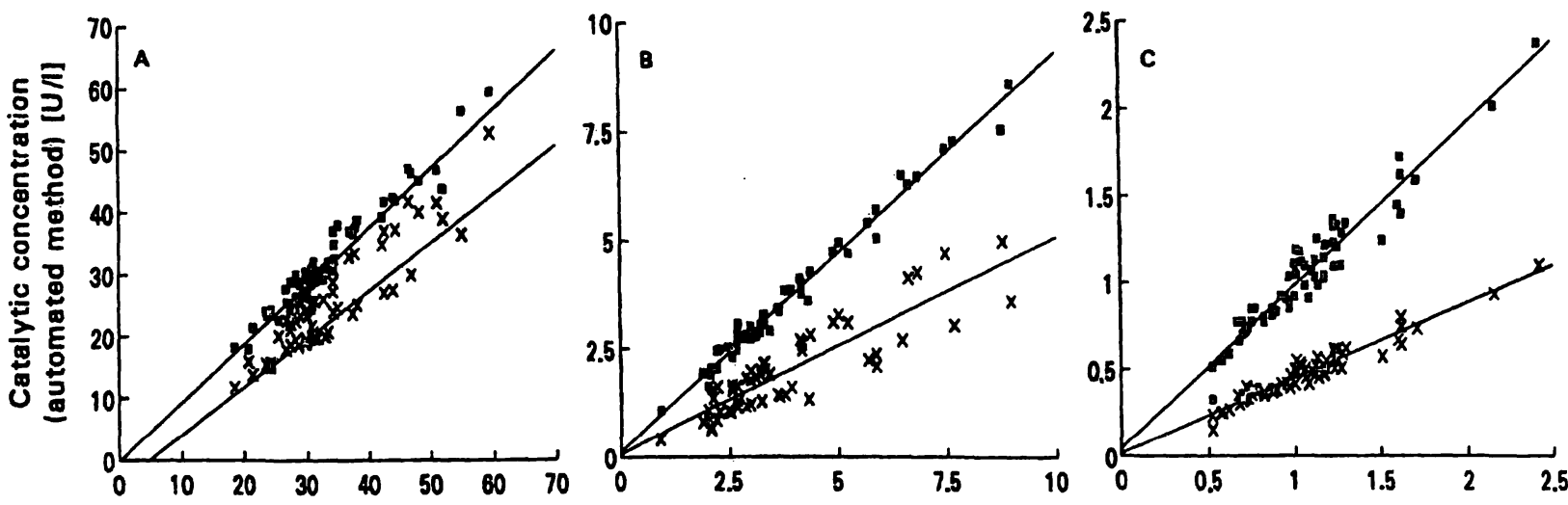

Catalytic concentration (manual method) [U/I]

Fig. 3 Comparison of the automated with the manual method using or not using the enzyme reference material as standard. Number of subjects: 60 .

$x$ without the use of the enzyme reference material. with the use of the enzyme reference material. a) $\mathrm{N}$-acetyl- $\beta-D$-glucosaminidase

$\mathrm{X}: \mathrm{r}=0.91, \mathrm{y}=-3.8+0.86 \mathrm{x} \quad$ a: $\mathrm{r}=0.97, \mathrm{y}=-0.28+0.98 \mathrm{x}$

b) $\beta$ - $D$-glucuronidase

$\mathrm{x}: \mathrm{r}=0.88, \mathrm{y}=0.06+0.5 \mathrm{x} \quad \mathrm{a}: \mathrm{r}=0.99, \mathrm{y}=0.087+0.94 \mathrm{x}$

c) $\beta$ - $D$-galactosidase

$\mathrm{x}: \mathrm{r}=0.96, \mathrm{y}=0.02+0.43 \mathrm{x} \quad$ a: $\mathrm{r}=0.96, \mathrm{y}=0.02+0.98 \mathrm{x}$ the $\mathrm{r}$ values to almost unity $(0.97,0.99$ and 0.96 for $\mathrm{N}$ acetyl- $\beta$ - $D$-glucosaminidase, $\beta$ - $D$-glucuronidase and $\beta$ $D$-galactosidase, respectively). Thus, the use of this material standard is recommended, together with the 4methylumbelliferone solution - of known concentration for routine instrument calibration.

\section{Discussion}

The introduction into the clinical laboratory market of routine autoanalysers suitable for fluorimetric assays, like the IL Monarch centrifugal analyser, prompted us to use this instrument for the optimized fluorimetric assay of lysosomal enzymes, which are already available as manual methods.

The results showed that the automated procedure presented here, using a stable liquid material as internal standard, is as sensitive as the manual reference method, but more precise than the latter, with coefficients of variation in the range of $3.6-6.9$, which are very low for

\section{References}

1. Woolen JV, Turner P. Plasma $\beta$-N-acetyl-D-glucosaminidase and $\beta$-D-glucuronidase in health and disease. Clin Chim Acta $1965 ; 12: 671-83$.

2. Niebes P. Determination of enzymes and degradation products of glycosaminoglycans metabolism in the serum of health and varicose subjects. Clin Chim Acta 1972; 42:399-408.

3. Calvo P, Barba JL, Cabezas JA. Serum $\beta$-D-glucuronidase, $\beta$ $D$-glucosidase, $\alpha$-L-fucosidase, $\alpha$-D-galactosidase levels in acute viral hepatitis, pancreatitis, myocardial infarction and breast cancer. Clin Chim Acta 1982; 11:15-9.

4. Reglero A, Carrettero MI, Cabezas JA. Increased serum $\alpha-L-$ fucosidase and $\beta-D-N$-acetylglucosiminidase activities in diabetic, cirrhotic and gastric cancer patients. Clin Chim Acta 1980; 103:155-8. enzyme assays. The automated method requires small amounts of undiluted plasma $(4-10 \mu \mathrm{l})$, covers a sufficiently wide range of enzyme concentration and is as simple and as cost effective as most routine serum enzyme assays. The availability of this method and of liquid stable materials for use as reference standards and for instrument calibration will enable large scale screening programmes on selected pathologies, as well as facilitating intra- and inter-laboratory quality control programmes. On this basis, the determination of selected enzymes of lýsosomal origin in plasma might gain sufficient analytical reliability and diagnostic utility to be included in current clinical enzymology.

\section{Acknowledgements}

This work was supported in part by grants from the "Italian Ministery of Education": MURST 40\% programme, from Lombardy Region (Ricerca biomedica finalizzata, grant n. 311), and Consiglio Nazionale delle Ricerche (C.N.R.), Progetto strategico per il mezzogiorno.

5. Hultberg $B$, Isaksson $A$. Isoenzyme pattern of serum $\beta$-hexosaminidase in liver disease, alcohol intoxication and pregnancy. Enzyme 1983; 30:166-71.

6. Koskinen $\mathrm{H}$, Jarvisolo J, Pitkanen E, Mutanen P, Zitting A. Serum $\beta$-D-acetylglucosaminidase and $\beta$-glucuronidase activities in silicosis patient and in workers exposed to silica dust. Br J Dis Chest 1984; 78:217-24.

7. Viganò A, Assael BM, Villa AD, Gagliardi L, Principi $N$, Ghezzi $P$, et al. N-acetyl- $\beta$-D-glucosaminidase (NAG) and NAG isoenzymes in children with upper and lower urinary tract infections. Clin Chim Acta 1983; 130:297-304.

8. Belfiore F, Lo Vecchio L, Napoli E, Borzi V. Increased $\beta-N$ acetylglucosaminidase activity in diabetes mellitus. Clin Chem $1974 ; 20: 1229-30$. 
9. Kohler E, Sheth KJ, Good TA. Plä̀sma acidic glycohydrolases in insulin-dependent diabetes mellitus. Acta Diabetol Lat 1981; 18:243-50.

10. Goi G, Fabi A, Lorenzi R, Lombardo A, Tettamanti G, Burlina $A B$, et al. Serum enzymes of lysosomal origin as indicators of the metabolic control in diabetes: comparison with glycated hemoglobin and albumin. Acta Diabetol Lat 1986; 23:117-25.

11. Goi G, Lombardo A, Fabi A, Burlina AB, Segalini G, Guagnellini $E$, et al. Serum enzymes of lysosomal origin as indicators of the metabolic control in non-insulin dependent diabetics. Acta Diabetol Lat 1987; 24:331-40.

12. Burlina AB, Goi G, Fabi A, Lombardo A, Gaburro D, Tettamanti $G$. Behaviour of some lysosomal enzyme in the plasma of insulin dependent diabetic patients during artificial pancreas treatment. Clin Biochem 1987; 20:423-7.

13. Yuen CT, Corbett CRR, Kind PRN, Thompson AE, Price RG. Isoenzymes of urinary $N$-acetyl- $\beta$-D-glucosaminidase (NAG) in patients with renal transplants. Clin Chim Acta 1987; $164: 339-50$

14. Severini G, Aliberti LM, Koch M, Capurso L, Tarquini M. Clinical evaluation of serum $\mathrm{N}$-acetyl- $\beta$-D-glucosaminidase as a liver function test. Biochem Med Metabol Biol 1990; 44:247-51.

15. Isaksson A, Hultberg B, Sundler $R$, Åkesson B. Uptake of $\beta$ hexosaminidase by nonparenchymal liver cells and peritoneal macrophages. Enzyme 1983; 30:230-8.

16. Chang CWT, Imai K, Chang YC, Hayashi T, Kohno H, Nagasue N, Nakamura T. Plasma lysosomal enzymes after liver transplantation in the pig. Enzyme 1991; 45:145-54.

17. Lombardo A, Caimi L, Marchesini S, Goi G, Tettamanti G. Enzymes of lysosomal origin in human plasma and serum: assay conditions and parameters influencing the assay. Clin Chim Acta 1980; 108:337-46.
18. Goi G, Bairati C, Roggi C, Maccarini L, Tettamanti G, Meloni $C$, et al. The lysosomal $N$-acetyl- $\beta$-D-glucosaminidase (NAG) isoenzymes in plasma: study of distribution in a general population by a simple routine chromatofocusing procedure. Clin Chim Acta 1993; 221:47-57.

19. Goi G, Besozzi M, Bairati C, Guagnellini E, Lombardo A, Tettamenti G. Preparation of a stable liquid material for calibration and quality control for lysosomal enzymes in plasma. Assay of enzymes of lysosomal origin in plasma, I. Eur J Clin Chem Clin Biochem 1992; 30:595-8.

20. Lombardo A, Goi G, Pistolesi E, Rocca E, Agosti S, Fabi A, et al. Behaviour of several enzymes of lysosomal origin in human plasma during pregnancy. Clin Chim Acta 1984; 143:253-64.

21. Krouwer JS. Observations on comparisons of within-run and day-to-day precision. Clin Chem 1981; 27:202.

22. NCCLS Document EP 10-T Preliminary evaluation of Clinical Chemistry methods 1989; 9.

23. Glick MR, Ryder KW, Jackson SA. Graphical comparison of interferences in clinical chemistry instrumentation. Clin Chem 1986; 32:470-5.

24. van Kampen EJ, Zijlstra WG. Determination of hemoglobin and its derivatives. Adv Clin Chem 1965; 8:141-87.

25. Snedecor GW, Cochran WG. Statistical methods. Ames: The Yowa State University Press 1967.

26. Deming WE. Statistical adjustment of data. New York: Wiley $\mathrm{J}$ and Sons, Publishers. 1943: 184.

Prof. Guido Tettamanti

Dipartimento di Chimica e Biochimica Medica

Università di Milano

Via Saldini, 50

I-20133 Milano

Italy 